\title{
Impact of sediment-seawater cation exchange on Himalayan chemical weathering fluxes
}

\author{
Maarten Lupker $^{1,2}$, Christian France-Lanord ${ }^{2}$, and Bruno Lartiges ${ }^{3}$ \\ ${ }^{1}$ Geological Institute, ETH Zurich, Zurich, 8092, Switzerland \\ ${ }^{2}$ Centre de Recherches Pétrographiques et Géochimiques (CRPG), CNRS-Université de Lorraine, \\ Vandoeuvre-les-Nancy, 54501, France \\ ${ }^{3}$ Géosciences Environement Toulouse (GET), Université Paul Sabatier, Toulouse, 31400, France
}

Correspondence to: Maarten Lupker (maarten.lupker@erdw.ethz.ch)

Received: 20 April 2016 - Published in Earth Surf. Dynam. Discuss.: 4 May 2016

Revised: 25 July 2016 - Accepted: 3 August 2016 - Published: 12 August 2016

\begin{abstract}
Continental-scale chemical weathering budgets are commonly assessed based on the flux of dissolved elements carried by large rivers to the oceans. However, the interaction between sediments and seawater in estuaries can lead to additional cation exchange fluxes that have been very poorly constrained so far. We constrained the magnitude of cation exchange fluxes from the Ganga-Brahmaputra river system based on cation exchange capacity (CEC) measurements of riverine sediments. CEC values of sediments are variable throughout the river water column as a result of hydrological sorting of minerals with depth that control grain sizes and surface area. The average CEC of the integrated sediment load of the Ganga-Brahmaputra is estimated ca. 6.5 meq $100 \mathrm{~g}^{-1}$. The cationic charge of sediments in the river is dominated by bivalent ions $\mathrm{Ca}^{2+}(76 \%)$ and $\mathrm{Mg}^{2+}(16 \%)$ followed by monovalent $\mathrm{K}^{+}(6 \%)$ and $\mathrm{Na}^{+}(2 \%)$, and the relative proportion of these ions is constant among all samples and both rivers. Assuming a total exchange of exchangeable $\mathrm{Ca}^{2+}$ for marine $\mathrm{Na}^{+}$yields a maximal additional $\mathrm{Ca}^{2+}$ flux of $28 \times 10^{9} \mathrm{~mol} \mathrm{yr}^{-1}$ of calcium to the ocean, which represents an increase of ca. $6 \%$ of the actual river dissolved $\mathrm{Ca}^{2+}$ flux. In the more likely event that only a fraction of the adsorbed riverine $\mathrm{Ca}^{2+}$ is exchanged, not only for marine $\mathrm{Na}^{+}$but also $\mathrm{Mg}^{2+}$ and $\mathrm{K}^{+}$, estuarine cation exchange for the GangaBrahmaputra is responsible for an additional $\mathrm{Ca}^{2+}$ flux of $23 \times 10^{9} \mathrm{~mol} \mathrm{yr}^{-1}$, while ca. $27 \times 10^{9} \mathrm{~mol} \mathrm{yr}^{-1} \mathrm{of}^{2}$ $\mathrm{Na}^{+}, 8 \times 10^{9} \mathrm{~mol} \mathrm{yr}^{-1}$ of $\mathrm{Mg}^{2+}$ and $4 \times 10^{9} \mathrm{~mol} \mathrm{yr}^{-1}$ of $\mathrm{K}^{+}$are re-absorbed in the estuaries. This represents an additional riverine $\mathrm{Ca}^{2+}$ flux to the ocean of $5 \%$ compared to the measured dissolved flux. About $15 \%$ of the dissolved $\mathrm{Na}^{+}$flux, $8 \%$ of the dissolved $\mathrm{K}^{+}$flux and $4 \%$ of the $\mathrm{Mg}^{2+}$ are reabsorbed by the sediments in the estuaries. The impact of estuarine sediment-seawater cation exchange appears to be limited when evaluated in the context of the long-term carbon cycle and its main effect is the sequestration of a significant fraction of the riverine $\mathrm{Na}$ flux to the oceans. The limited exchange fluxes of the Ganga-Brahmaputra relate to the lower than average CEC of its sediment load that do not counterbalance the high sediment flux to the oceans. This can be attributed to the nature of Himalayan river sediment such as low proportion of clays and organic matter.
\end{abstract}

1

Chemical weathering on the continents is a primary source of dissolved elements delivered to the oceans. The flux of weathering products, mainly exported through the world rivers, exerts a first-order control on oceanic biogeochemical cycles. On geological timescales, silicate weathering also represents a carbon sink that balances mantle and metamorphic $\mathrm{CO}_{2}$ input to the atmosphere, thereby affecting the global climate (Walker et al., 1981). During silicate weathering by acid derived from atmospheric $\mathrm{CO}_{2}, \mathrm{Ca}$ ions are released and transported along with bicarbonate ions to the oceans, where they are eventually precipitated as carbonates. This mechanism transfers carbon from the atmospheric to 
the geologic reservoir following the Ebelman-Urey reaction (Ebelmen, 1845; Urey, 1952):

$$
\begin{aligned}
& \mathrm{CaSiO}_{3}+2 \mathrm{CO}_{2}+\mathrm{H}_{2} \mathrm{O} \rightarrow \mathrm{Ca}^{2+} \\
& +2 \mathrm{HCO}_{3}^{-}+\mathrm{SiO}_{2} \mathrm{Ca}^{2+}+2 \mathrm{HCO}_{3}^{-} \\
& \rightarrow \mathrm{CaCO}_{3}+\mathrm{CO}_{2}+\mathrm{H}_{2} \mathrm{O} .
\end{aligned}
$$

Quantifying the weathering flux exported to the oceans is therefore crucial to assess the role of weathering in the global carbon cycle and further compare it to other mechanisms that control atmospheric $\mathrm{CO}_{2}$ content on geological timescales. It is further highly relevant to a broader understanding of oceanic geochemical cycles.

Modern continental weathering fluxes have largely been derived from the study of dissolved elements exported by rivers (Gaillardet et al., 1999). However, most of these fluxes do not account for elements delivered to the oceans through cation exchange, when river sediments are transferred through estuaries and towards the ocean. Sediments in an aqueous solution such as river or oceanic water reversibly adsorb cations in equilibrium with the surrounding environment. The nature of these adsorbed cations evolves with changes in the chemical composition of the surrounding solution. The most radical change in surrounding water chemical composition that the suspended sediment undergoes in a fluvial system occurs in estuaries across the salinity gradient. In the riverine environment, sediment surfaces are mainly occupied by adsorbed $\mathrm{Ca}^{2+}$ species, which is the dominant dissolved cation in rivers. When transferred to the oceans, the $\mathrm{Ca}^{2+}$ adsorbed on sediment surfaces is partially exchanged for $\mathrm{Na}^{+}, \mathrm{Mg}^{2+}$ and $\mathrm{K}^{+}$(Sayles and Mangelsdorf, 1977), which are more abundant in ocean waters. These exchange reactions represent an additional source of $\mathrm{Ca}$ to the oceans and a potential sink for $\mathrm{Na}, \mathrm{Mg}$ and $\mathrm{K}$. These estuarine exchange reactions cannot be directly compared to additional weathering fluxes from the chemical weathering of sediments in seawater that has recently been suggested (Jones et al., 2012) as the processes are different. Chemical weathering in the presence of seawater involves the formation of secondary minerals (Jones et al., 2012), which is not the case for exchange reactions.

For the Amazon, Sayles and Mangelsdorf (1979) estimated that cation exchange fluxes remained under $10 \%$ of the dissolved flux for the major elements $\mathrm{Na}, \mathrm{Mg}, \mathrm{Ca}$ and $\mathrm{K}$. On a global scale, first-order estimates suggest that cation exchange can account for an extra $\mathrm{Ca}^{2+}$ flux to the ocean ranging from 5 to $20 \%$ of the riverine dissolved flux (Berner and Berner, 2012; Berner et al., 1983; Holland, 1978). Nevertheless, these exchange fluxes to the oceans have received little attention and are currently poorly constrained. Global estimates mainly rely on the upscaling of the Amazon data from Sayles and Mangelsdorf (1979) and the magnitude of these fluxes has so far not been assessed for other major river systems.
In an effort to refine the weathering budget of the Himalayan range and its implications for the long-term carbon cycle, we evaluate the exchange flux delivered to the oceans by the Ganga and Brahmaputra rivers. The GangaBrahmaputra $(G \& B)$ is the largest river in terms of sediment export, with a total suspended and bedload sediment flux of ca. $10^{9} \mathrm{tyr}^{-1}$ transported from the Himalayan range to the Bay of Bengal (BoB; RSP, 1996). The high sediment to dissolved load ratio of the G\&B of ca. 11 (Galy and France-Lanord, 2001), more than double the world average (ca. 5; Milliman and Farnsworth, 2011), could potentially yield significant cation exchange fluxes that need to be properly quantified. Raymo and Ruddiman (1992) proposed that Himalayan weathering generated a major uptake of atmospheric carbon during the Neogene, potentially triggering the Cenozoic climate cooling. This suggestion was moderated based on the observation that Himalayan silicates are mostly alkaline and therefore generate a flux of alkalinity linked to $\mathrm{Na}$ and $\mathrm{K}$ ions that cannot lead to precipitation of carbonate in the marine environment (France-Lanord and Derry, 1997; Galy and France-Lanord, 1999). Nevertheless, cation exchange on sediment surfaces at the river-ocean transition can potentially exchange $\mathrm{Na}^{+}$for $\mathrm{Ca}^{2+}$, strengthening the subsequent carbonate precipitation. Earlier studies on the carbon budget of Himalayan weathering used a rough approximation of this process (France-Lanord and Derry, 1997), and in order to better evaluate the carbon budget of Himalayan silicate weathering, it is necessary to assess the importance of cation exchange fluxes based on the specific physico-chemical properties of G\&B suspended sediments.

\section{Samples and methods}

\subsection{Sampling}

Sediments used in this work were sampled at the mouth of the Ganga and Brahmaputra rivers as well as their confluence in lower Meghna in Bangladesh during monsoon seasons between 2002 and 2010 (Fig. 1). These sample locations integrate all Himalayan tributaries and therefore cover the entire sediment flux exported by the G\&B basin. These sampling locations are also located upstream of the G\&B estuary and can therefore be considered as true riverine samples. Suspended sediments were sampled along depth profiles in the centre of the active channel in order to capture the full variability of transported sediments (Lupker et al., 2011). Bedload samples were dredged from the channel as well. Sediments were filtered at $0.2 \mu \mathrm{m}$ within $24 \mathrm{~h}$ of sampling and freeze-dried back in the lab. Sediment contact with anything else than river water was prevented to avoid biases in the composition of bound cations due to "rinsing effects" (Sayles and Mangelsdorf, 1977). The major element composition of sediments was determined by ICP-OES after $\mathrm{LiBO}_{2}$ fusion at SARM-CRPG (Nancy, France). 


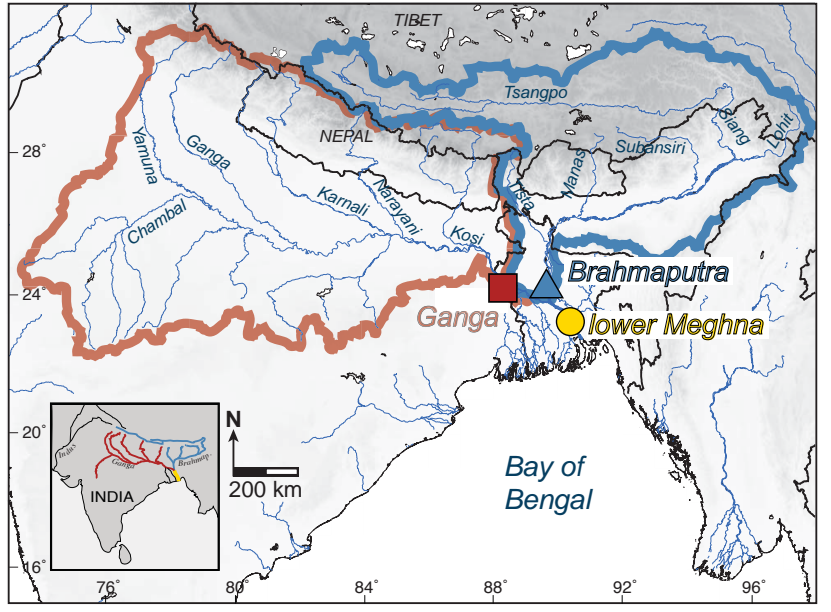

Figure 1. Map of the Ganga and Brahmaputra basins (respectively delimited in red and blue) and sampling locations of sediments used in this study on the Ganga River, the Brahmaputra River and the lower Meghna River, which is the confluence of both rivers.

\subsection{Cation exchange capacity determination}

The cation exchange capacity (CEC) is defined as the number of cations bound to mineral surface charges that can be reversibly exchanged. In this work, cation exchange capacity was measured by displacing the adsorbed ions with cobalt hexammine ("CoHex", $\mathrm{Co}\left(\mathrm{NH}_{3}\right)_{6}^{3+}$ ). $\mathrm{CoHex}$ is a stable organometallic compound that effectively displaces major cations while keeping the $\mathrm{pH}$ of the sample constant (Ciesielski et al., 1997; Orsini and Remy, 1976). The CoHex solution is slightly acidic and may lead to the dissolution of sedimentary carbonates during exchange. To avoid this carbonate dissolution, the CoHex solution was saturated with pure calcite before exchange (Dohrmann and Kaufhold, 2009). Between 1 and $2 \mathrm{~g}$ of sediments was reacted with $30 \mathrm{~mL}$ of a calcite-saturated CoHex solution for $2 \mathrm{~h}$. After centrifugation, the remaining cobalt concentration in the supernatant was determined by spectrometric UV absorbance measurements (Aran et al., 2008), which by difference with the initial cobalt concentration of the solution yields a first estimate of the total CEC of the sediments $\left(\mathrm{CEC}_{\mathrm{UV}}\right)$. Additionally, major cations $\left(\mathrm{Ca}^{2+}, \mathrm{Mg}^{2+}, \mathrm{Na}^{+}, \mathrm{K}^{+}\right)$released by the sediments during exchange were determined by atomic absorption spectrometry at SARM-CRPG on the same solution, using a non-reacted CoHex solution as reference. The sum of the released cations provides a second determination of the total CEC of the sediments $\left(\mathrm{CEC}_{\Sigma_{\text {cat }}}\right)$. No systematic differences between $\mathrm{CEC}_{\mathrm{UV}}$ and $\mathrm{CEC}_{\Sigma_{\text {cat }}}$ are observed (Fig. 2), which emphasizes that no significant numbers of other cations are released during exchange or through mineral dissolutions such as dolomite. Repeated measurements showed that the reproducibility of both measurements is better than $10 \%$. Freeze drying the sediment samples prior to CEC analyses did not affect their CEC behaviour since dif-

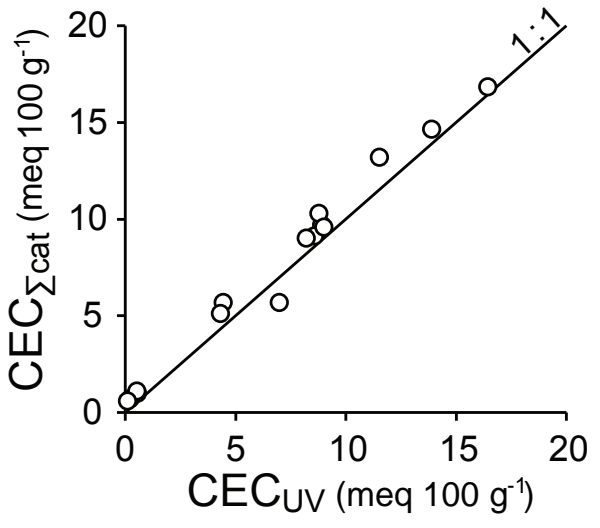

Figure 2. Total CEC determined by the sum of cations $\left(\mathrm{Ca}^{2+}+\mathrm{Mg}^{2+}+\mathrm{Na}^{+}+\mathrm{K}^{+}\right)$released after sediment exchange with a CoHex solution $\left(\mathrm{CEC}_{\Sigma_{\mathrm{cat}}}\right)$ as a function of the total CEC determined based on the absorption of cobalt ions from the CoHex solution after exchange $\left(\mathrm{CEC}_{\mathrm{UV}}\right)$. For each sample $\mathrm{CEC}_{\Sigma_{\mathrm{cat}}}$ and $\mathrm{CEC}_{\mathrm{UV}}$ were determined on the same CoHex solution.

ferent splits of sediments conserved in river water until exchange and splits subsequently freeze-dried showed similar CEC values within uncertainty.

\section{Cation exchange capacity of Himalayan sediments}

\subsection{Total cation exchange capacity}

The CEC of river sediments in the Ganga, Brahmaputra and lower Meghna are reported in Table 1. The CEC of sediments is correlated with the sediment sampling depth. Surface sediments have generally a higher CEC than coarse bedload sediments. This is further illustrated by the positive correlation between CEC and the $\mathrm{Al} / \mathrm{Si}$ ratio of sediments (Fig. 3). $\mathrm{Al} / \mathrm{Si}$ is well correlated with grain size, which is controlled by hydraulic mineral sorting of sediments within the water column (Bouchez et al., 2011; Lupker et al., 2011, 2012). The variable $\mathrm{Al} / \mathrm{Si}$ ratio of sediments in the water column is, to a first order, the result of binary mixing between Si-rich, coarse-grained quartz bottom sediments and Al-rich phylosilicates and clays that are relatively enriched in surface sediments. Surface sediments also have a higher surface area favouring adsorption compared to bedload samples (Galy et al., 2008). Sediments from the Ganga show higher CECs for a given $\mathrm{Al} / \mathrm{Si}$ ratio compared to sediments from the Brahmaputra. Ganga sediments also have a higher surface area (Galy et al., 2008), which can be attributed to a higher abundance of mixed layer and smectite clays of Ganga sediments relative to the Brahmaputra (Heroy et al., 2003; Huyghe et al., 2011). Additionally, the CEC of surface sediments may also be enhanced because of the higher organic matter content of river surface samples (Galy et al., 2008) that can provide additional exchange capacity (e.g. Thompson et al., 1989; Turpault et al., 1996). The variable CEC 


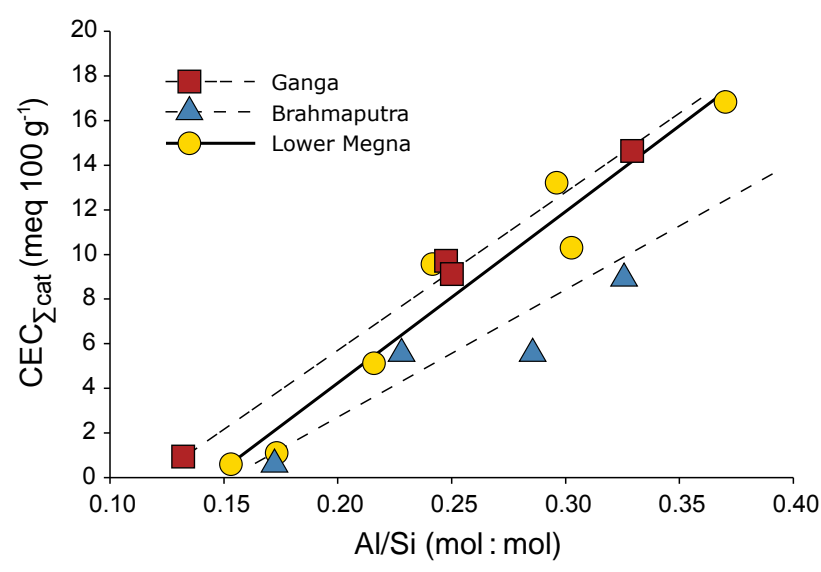

Figure 3. CEC of sediment samples from the Ganga, Brahmaputra and lower Meghna rivers as a function of $\mathrm{Al} / \mathrm{Si}$ that is used here as a proxy for grain size and sediment sorting in the river channel.

of sediments in the water column and amongst river reaches can therefore be tentatively summarized as resulting from the mineralogical and grain-size control on the surface area and organic matter loading of the sediments (Malcolm and Kennedy, 1970).

\subsection{Nature of adsorbed cations}

Figure 4 shows the molar fraction of each major cation adsorbed onto the sediments delivered to the BoB. $\mathrm{Ca}^{2+}$ and $\mathrm{Mg}^{2+}$ are the dominant adsorbed cations in river water, with 76 and $16 \%$ of the total exchangeable cations, respectively. $\mathrm{Na}^{+}$and $\mathrm{K}^{+}$respectively account for 1 and $7 \%$ of the total adsorbed species. However, in contrast to total CEC, the nature of the exchangeable cations is not dependent on the $\mathrm{Al} / \mathrm{Si}$ ratio of the sediments and is constant amongst all samples. The partitioning of exchangeable cations bound to the riverine sediments is therefore not controlled by grain size or mineralogical sorting in the water column. These exchangeable compositions are also very similar for Ganga, Brahmaputra and lower Meghna sediments and for samples collected over different years.

The composition of sediment exchangeable cations is, to a first order, imposed by the dissolved composition of the river water transporting these sediments. For the two most abundant adsorbed cations, the binary $\mathrm{Ca} / \mathrm{Mg}$ exchange is commonly described as an exchange isotherm with an equilibrium constant $K_{v}$ (Sayles and Mangelsdorf, 1979), such that

$$
\frac{X_{\mathrm{Ca}}}{X_{\mathrm{Mg}}}=K_{v} \cdot\left(\frac{a_{\mathrm{Ca}}}{a_{\mathrm{Mg}}}\right)^{p},
$$

where $X_{\mathrm{Ca}}$ and $X_{\mathrm{Mg}}$ are the fraction of adsorbed cations, $a_{\mathrm{Ca}}$ and $a_{\mathrm{Mg}}$ are the cation activity in the river water, and $p$ is a constant. The chemical composition of the river water directly in contact with the sampled sediments has not been

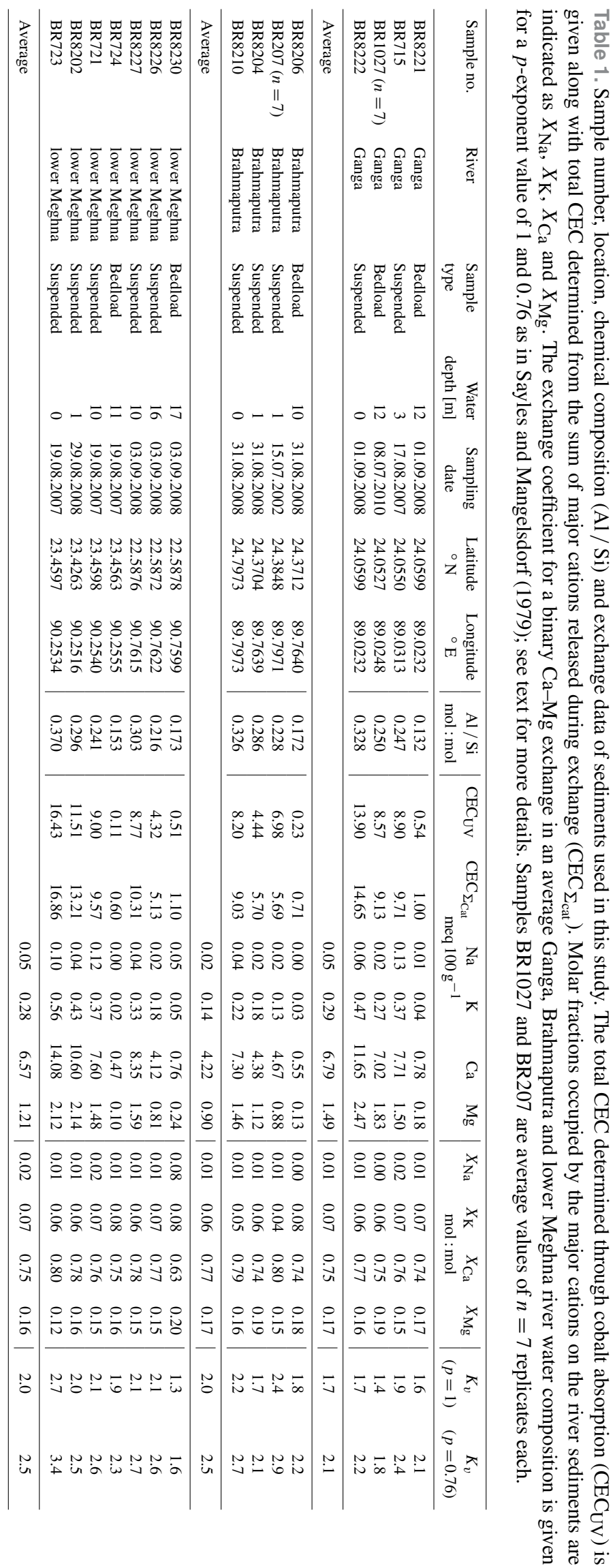

www.earth-surf-dynam.net/4/675/2016/ 


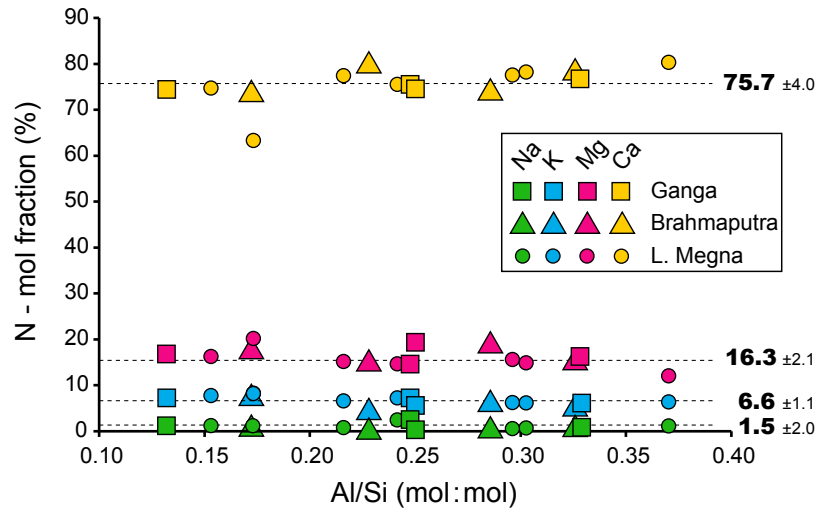

Figure 4. Molar fraction of major cations absorbed to sediments in the Ganga, Brahmaputra and lower Meghna rivers as a function of $\mathrm{Al} / \mathrm{Si}$.

systematically measured. However, the constant composition of exchangeable cations for sediments sampled at different seasons suggests that a first-order determination of $K_{v}$ can be made using the average dissolved composition of the Ganga, Brahmaputra and lower Meghna (Galy and France-Lanord, 1999). The equilibrium constant, $K_{v}$, for sediments of the Ganga, Brahmaputra and lower Meghna is relatively similar (between 1.7 and 2 for $p=1$ ) despite the use of average dissolved river water compositions that do not take into account for the compositional variability of these rivers (Galy and France-Lanord, 1999; Singh et al., 2005). Using a $p$ value of 0.76 as found in Amazon sediments (Sayles and Mangelsdorf, 1979), the calculated $K_{v}$ ranges from 2.1 to 2.5 , also in agreement with the equilibrium constants found on the Amazon (Table 1). These very similar constants show that the behaviour of Himalayan sediments with respect to the cation exchange composition is very similar to the sediments transported by the Amazon. These similarities most probably stem from the first-order resemblance of the mineralogical composition of both rivers (Garzanti et al., 2011; Martinelli et al., 1993).

\subsection{Exchangeable flux to the BoB}

In order to derive the flux of exchangeable cations that can be delivered to the BoB by Himalayan sediments, it is necessary to take into account the variability in the CEC of sediments with the water depth. The average CEC of sediments exported to the $\mathrm{BoB}$ can be constrained using the average $\mathrm{Al} / \mathrm{Si}$ ratio of the sediments owing to the linear correlation between $\mathrm{CEC}$ and $\mathrm{Al} / \mathrm{Si}$ (Fig. 3). Lupker et al. (2011) constrained the average Al / Si of Ganga sediments in Bangladesh to 0.23 . Changes in the $\mathrm{Al} / \mathrm{Si}$ ratio of sediments during transport are mainly the result of sequestration of quartz-rich sediments in the subsiding floodplain. In the case of the Ganga, the sequestrated flux is limited and the $\mathrm{Al} / \mathrm{Si}$ ratio of sediments in Bangladesh is close to that in- ferred for the Himalayan crust. The major immobile element content ( $\mathrm{Al}, \mathrm{Si}$ and $\mathrm{Fe}$ ) of Brahmaputra sediments is very similar to that of Ganga sediments (Lupker, 2011), suggesting that the parent material has a very similar composition. Furthermore, the constricted morphology of the Brahmaputra floodplain does not favour high sedimentation fluxes in the floodplain. We therefore suppose here that the average $\mathrm{Al} / \mathrm{Si}$ of the Brahmaputra is very similar to that of Ganga sediments.

Using an $\mathrm{Al} / \mathrm{Si}$ ratio of $0.23( \pm 0.01)$ yields an average total CEC of $8.0( \pm 0.9), \quad 4.2( \pm 1.2)$ and $6.5( \pm 1.3) \mathrm{meq} 100 \mathrm{~g}^{-1}$ for Ganga, Brahmaputra and lower Meghna sediments, respectively. The average lower Meghna CEC deduced from the regression through the analysed sediments is very similar to the ca. $6.0( \pm 1.1) \mathrm{meq} 100 \mathrm{~g}^{-1} \mathrm{CEC}$ that would be expected from the mixing of $550 \times 10^{6} \mathrm{tyr}^{-1}$ of Ganga sediments and $590 \times 10^{6} \mathrm{tyr}^{-1}$ of Brahmaputra sediments (RSP, 1996). For a combined Ganga and Brahmaputra sediment flux of $1.14 \times 10^{9} \mathrm{tyr}^{-1}$, the total exchange capacity of the sediments amounts to $74.1( \pm 14.8) \times 10^{12} \mathrm{meq} \mathrm{yr}^{-1}$. The maximum exchangeable flux is reported in Table 2. During exchange with seawater, river sediments mainly lose $\mathrm{Ca}^{2+}$ to the ocean while adsorbing $\mathrm{Mg}^{2+}, \mathrm{Na}^{+}$and $\mathrm{K}^{+}$(Sayles and Mangelsdorf, 1977, 1979). Assuming a total exchange of $\mathrm{Ca}^{2+}$ (the dominant cation in riverine water) for $\mathrm{Na}^{+}$(the dominant cation in seawater) during the transfer of sediments to the ocean yields a maximum exchange flux of $28( \pm 6) \times 10^{9} \mathrm{~mol} \mathrm{yr}^{-1}$ $\mathrm{Ca}^{2+}$ to the Indian Ocean, while $56( \pm 12) \times 10^{9} \mathrm{~mol} \mathrm{yr}^{-1}$ $\mathrm{Na}^{+}$is adsorbed onto the sediments. These additional $\mathrm{Ca}$ and lower $\mathrm{Na}$ fluxes to the ocean are not accounted for by modern dissolved riverine fluxes.

However, Sayles and Mangelsdorf $(1977,1979)$ showed that only a fraction of adsorbed $\mathrm{Ca}^{2+}$ is exchanged during prolonged contact of sediments and clays with seawater and that these cations are not only exchanged for $\mathrm{Na}^{+}$but also partially for $\mathrm{Mg}^{2+}$ and $\mathrm{K}^{+}$. In their experiments, the authors found that ca. $82 \%$ of the adsorbed riverine $\mathrm{Ca}^{2+}$ is exchanged for $\mathrm{Na}^{+}, \mathrm{Mg}^{2+}$ and $\mathrm{K}^{+}$in respective molar proportions of 58, 32 and $10 \%$. For the estimation of the most probable flux of cations exchanged by G\&B sediments upon entry in the Indian Ocean, we assume that the exchanged proportion measured by Sayles and Mangelsdorf $(1977,1979)$ on Amazon sediments also applies here. This is a reasonable assumption as the aforementioned studies show that the nature of exchange reactions (i.e. the relative proportions of cations exchanged during transfer to the ocean) is very similar among the different samples studied, irrespective of sampling location within the Amazon Basin, composition or grain size. Furthermore, we showed in the previous section that the equilibrium constant $K_{v}$ between different cations in solution and adsorbed to the sediments sampled in the Ganga, Brahmaputra and lower Meghna is in the same range as the equilibrium constant found on Amazon sediments, suggesting a similar behaviour of these two river systems with respect to cation 
Table 2. Sediment fluxes (RSP, 1996), average CEC of the sediments and exchangeable flux of major cations bound to the river sediments.

\begin{tabular}{|c|c|c|c|c|c|c|c|}
\hline River & $\begin{array}{c}\text { Average } \\
\text { CEC } \\
\text { meq } 100^{-1} \mathrm{~g}\end{array}$ & $\begin{array}{l}\text { Sediment } \\
\text { flux } \\
\text { Mt yr }^{-1}\end{array}$ & $\begin{array}{c}\text { Total } \\
\text { exchangeable } \\
1 \times 10^{12} \text { meq yr }^{-1}\end{array}$ & $\begin{array}{c}\mathrm{Na} \\
\text { exchangeable }\end{array}$ & $\begin{array}{c}\mathrm{K} \\
\text { exchangeable } \\
1 \times 10^{12}\end{array}$ & $\begin{array}{l}\text { Ca } \\
\text { exchangeable } \\
\text { neq } \mathrm{yr}^{-1}\end{array}$ & $\begin{array}{c}\mathrm{Mg} \\
\text { exchangeable }\end{array}$ \\
\hline Ganga & $8.0( \pm 0.9)$ & 550 & $44.0( \pm 5.0)$ & $0.7( \pm 0.7)$ & $2.9( \pm 0.6)$ & $33.3( \pm 4.2)$ & $7.2( \pm 1.2)$ \\
\hline Brahmaputra & $4.2( \pm 1.2)$ & 590 & $24.8( \pm 7.1)$ & $0.4( \pm 0.4)$ & $1.6( \pm 0.5)$ & $18.8( \pm 5.5)$ & $4.0( \pm 1.3)$ \\
\hline Lower Meghna & $6.5( \pm 1.3)$ & 1140 & $74.1( \pm 14.8)$ & $1.1( \pm 1.1)$ & $4.9( \pm 1.3)$ & $56.1( \pm 11.6)$ & $12.1( \pm 2.9)$ \\
\hline
\end{tabular}

Table 3. Total exchangeable flux of major cations bound to the sediment in river water and most probable exchange fluxes taking place during interaction of G\&B sediments with seawater based on the measured total exchangeable cations and the effective exchange proportions of Sayles and Mangelsdorf $(1977,1979)$. These fluxes are compared to the riverine dissolved fluxes as given by Galy and France-Lanord (1999).

\begin{tabular}{|c|c|c|c|c|c|}
\hline & & & Ganga & Brahmaputra & Lower Meghna \\
\hline $\mathrm{Na}$ & $\begin{array}{l}\text { Total exchangeable } \\
\text { Riverine dissolved flux } \\
\text { Total ex. }-\% \text { of dissolved } \\
\text { Probable exchange } \\
\text { Prob. ex. }-\% \text { of dissolved }\end{array}$ & $\times 10^{9} \mathrm{~mol} \mathrm{yr}^{-1}$ & $\begin{array}{c}0.7( \pm 0.7) \\
128 \\
0.5 \% \\
-15.8(4.4) \\
12 \%\end{array}$ & $\begin{array}{c}0.4( \pm 0.4) \\
55 \\
0.7 \% \\
-8.9( \pm 2.5) \\
16 \%\end{array}$ & $\begin{array}{c}1.1( \pm 1.1) \\
183 \\
0.6 \% \\
-26.6( \pm 7.3) \\
15 \%\end{array}$ \\
\hline $\mathrm{K}$ & $\begin{array}{l}\text { Total exchangeable } \\
\text { Riverine dissolved flux } \\
\text { Total ex. }-\% \text { of dissolved } \\
\text { Probable exchange } \\
\text { Prob. ex. }-\% \text { of dissolved }\end{array}$ & $\times 10^{9} \mathrm{~mol} \mathrm{yr}^{-1}$ & $\begin{array}{c}2.9( \pm 0.6) \\
29 \\
10 \% \\
-2.7( \pm 0.7) \\
9 \%\end{array}$ & $\begin{array}{c}1.6( \pm 0.5) \\
29 \\
6 \% \\
-1.5( \pm 0.4) \\
5 \%\end{array}$ & $\begin{array}{c}4.9( \pm 1.3) \\
58 \\
8 \% \\
-4.5( \pm 1.5) \\
8 \%\end{array}$ \\
\hline $\mathrm{Ca}$ & $\begin{array}{l}\text { Total exchangeable } \\
\text { Riverine dissolved flux } \\
\text { Total ex. }-\% \text { of dissolved } \\
\text { Probable exchange } \\
\text { Prob. ex. }-\% \text { of dissolved }\end{array}$ & $\times 10^{9} \mathrm{~mol} \mathrm{yr}^{-1}$ & $\begin{array}{c}16.7( \pm 2.1) \\
252 \\
7 \% \\
13.7( \pm 2.2) \\
6 \%\end{array}$ & $\begin{array}{c}9.4( \pm 2.8) \\
211 \\
4 \% \\
7.7( \pm 1.2) \\
4 \%\end{array}$ & $\begin{array}{c}28.1( \pm 5.8) \\
463 \\
6 \% \\
23.0( \pm 3.7) \\
5 \%\end{array}$ \\
\hline $\mathrm{Mg}$ & $\begin{array}{l}\text { Total exchangeable } \\
\text { Riverine dissolved flux } \\
\text { Total ex. }-\% \text { of dissolved } \\
\text { Probable exchange } \\
\text { Prob. ex. }-\% \text { of dissolved }\end{array}$ & $\times 10^{9} \mathrm{~mol} \mathrm{yr}^{-1}$ & $\begin{array}{c}3.6( \pm 0.6) \\
93 \\
4 \% \\
-4.5( \pm 1.2) \\
5 \%\end{array}$ & $\begin{array}{c}2.0( \pm 0.7) \\
94 \\
2 \% \\
-2.5( \pm 0.7) \\
3 \%\end{array}$ & $\begin{array}{c}6.1( \pm 1.5) \\
187 \\
3 \% \\
-7.6( \pm 2.1) \\
4 \%\end{array}$ \\
\hline
\end{tabular}

exchange. A reasonable estimate of the effective exchanged flux in the G\&B estuary can therefore be made assuming that $82 \%$ of the total $\mathrm{Ca}^{2+}$ exchangeable flux is effectively exchanged for $\mathrm{Na}^{+}, \mathrm{Mg}^{2+}$ and $\mathrm{K}^{+}$. This estimation suggests that ca. $23( \pm 4) \times 10^{9} \mathrm{~mol}$ of $\mathrm{Ca}^{2+}$ is desorbed from the sediments in the $\mathrm{BoB}$, while $27( \pm 8) \times 10^{9} \mathrm{~mol} \mathrm{Na}^{+}$, $5( \pm 2) \times 10^{9} \mathrm{~mol} \mathrm{~K}^{+}$, and $8( \pm 3) \times 10^{9} \mathrm{~mol} \mathrm{Mg}^{2+}$ are reabsorbed (Table 3 ). The main exchange reaction is therefore still the exchange of riverine $\mathrm{Ca}^{2+}$ for marine $\mathrm{Na}^{+}$, but nonnegligible amounts of $\mathrm{K}^{+}$and $\mathrm{Mg}^{2+}$ are fixed in the marine environment by the sediments.

\subsection{Comparison with G\&B dissolved fluxes}

To evaluate the importance of cation exchange fluxes to the ocean, we compare the maximum and probable exchange fluxes derived above to the dissolved flux exported by the G\&B. Galy and France-Lanord (1999) estimated that the G\&B export an annual molar flux of $183 \times 10^{9}$ $\mathrm{Na}^{+}, 59 \times 10^{9} \mathrm{~K}^{+}, 462 \times 10^{9} \mathrm{Ca}^{2+}$ and $187 \times 10^{9} \mathrm{Mg}^{2+}$. These estimates are close to the fluxes estimated from the GEMS/Water Programme (UNESCO) and show the dominance of the $\mathrm{Ca}^{2+}$ flux, largely derived from carbonate dissolution. Assuming a total replacement of adsorbed $\mathrm{Ca}^{2+}$ with seawater $\mathrm{Na}^{+}$, the maximum cation exchange flux would be $+28( \pm 6) \times 10^{9} \mathrm{~mol} \mathrm{yr}^{-1} \mathrm{Ca}^{2+}$ and $-56( \pm 12) \times 10^{9} \mathrm{~mol} \mathrm{yr}^{-1} \mathrm{Na}^{+}$to the dissolved flux. This would increase the riverine $\mathrm{Ca}^{2+}$ flux by ca. $6 \%$ and decrease the $\mathrm{Na}^{+}$flux by $32 \%$ (Fig. 5). However, as discussed earlier, total cation exchange is not expected and a more probable exchange flux can be determined from the work by Sayles and Mangelsdorf (1979) on the Amazon. This more probable estimate suggests that the cation exchange flux represents an addition of ca. $5 \%$ of the dissolved $\mathrm{Ca}^{2+}$ flux and a subtraction of $16 \%$ of the dissolved $\mathrm{Na}^{+}$flux, $8 \%$ of the 


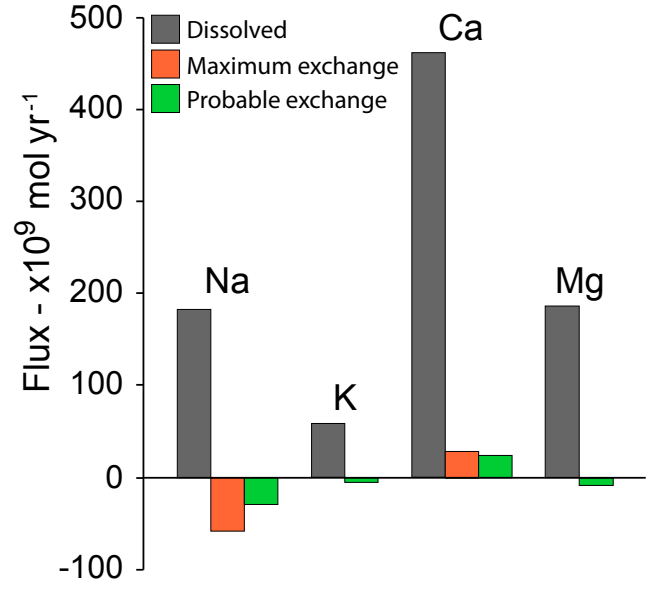

Figure 5. Maximum cation exchange fluxes (for a complete exchange of riverine $\mathrm{Ca}^{2+}$ for $\mathrm{Na}^{+}$) and more probable exchange fluxes (partial exchange of riverine $\mathrm{Ca}^{2+}$ for $\mathrm{Mg}^{2+}, \mathrm{K}^{+}$and $\mathrm{Na}^{+}$) based on exchange data of Sayles and Mangelsdorf $(1977,1979)$ of G\&B sediments. These exchange fluxes are compared to the total dissolved fluxes exported by the G\&B as estimated by Galy and France-Lanord (1999).

dissolved $\mathrm{K}^{+}$flux and $4 \%$ of the dissolved $\mathrm{Mg}^{2+}$ flux (Table 3, Fig. 5). The main effect of estuarine cation exchange for the Himalayan weathering budget is therefore a moderate but significant decrease in the overall $\mathrm{Na}^{+}$flux to the Indian Ocean since about one-sixth of the riverine flux is reabsorbed. The increase in riverine $\mathrm{Ca}^{2+}$ and decrease in $\mathrm{K}^{+}$ and $\mathrm{Mg}^{2+}$ fluxes remain limited.

\section{Discussion}

\subsection{Magnitude of cation exchange fluxes}

The exchange fluxes of G\&B sediments are of the order of a few percent of the riverine dissolved fluxes exported to the BoB. Despite the fact that the G\&B sediment flux is of the same order of magnitude as that of the Amazon River (Milliman and Farnsworth, 2011), the cation exchange flux of the G\&B appears lower by a factor 3 to 5 depending on the element compared to that determined for the Amazon by Sayles and Mangelsdorf (1979). This difference can be attributed to the lower average CEC value of ca. 6 meq $100 \mathrm{~g}^{-1}$ of the G\&B sediments compared to the ca. 22 meq $100 \mathrm{~g}^{-1}$ of Amazon sediments (Sayles and Mangelsdorf, 1979) that compensates for the high sediment yield of the Himalayan system. The overall low CEC of G\&B sediments also limits the relative importance of cation exchange on the dissolved fluxes. Even though the suspended to dissolved load ratio of the $G \& B$ is almost 3 times higher than that of the Amazon River (ca. 4; Milliman and Farnsworth, 2011), the effect of cation exchange is comparable to an increase of ca. 4 to $5 \%$ in the $\mathrm{Ca}^{2+}$ dissolved flux and a decrease of 4 to $8 \%$ in the $\mathrm{Mg}^{2+}$ and 6 to $8 \%$ in the $\mathrm{K}^{+}$dissolved fluxes (Sayles and
Mangelsdorf, 1979). The effect of riverine $\mathrm{Na}^{+}$re-adsorption is more substantial with a decrease of ca. $16 \%$ for the G\&B compared to the $6 \%$ determined for the Amazon, but this can mainly be attributed to the high dissolved $\mathrm{Na}$ flux of the Amazon. If a CEC value of world average river sediments of 18 meq $100 \mathrm{~g}^{-1}$ is retained (Berner and Berner, 1996; Holland, 1978), the total riverine cation exchangeable flux would also be higher by a factor of ca. 3 and yield an additional $\mathrm{Ca}^{2+}$ flux in excess of 15 to $18 \%$ compared to the actual dissolved $\mathrm{Ca}^{2+}$ flux. This difference highlights the importance of assessing the average CEC on a river-by-river basis.

The relatively low CEC values of G\&B sediments can be linked to the dominance of physical erosion in the Himalayan system, which does not favour the formation of high-area clay minerals (smectite) and leads to the export of clays dominated by illite and overall coarse-grained material with low surface areas (Galy et al., 2008). CEC exchange fluxes can be expected to scale with the magnitude of sediment fluxes, which means that the underestimation of modern dissolved chemical weathering fluxes is greatest in the most active areas with highest dissolved fluxes (West et al., 2005). However, it seems unlikely that this scaling is linear since active erosion processes do not necessarily favour high-surface-area mineral formations and hence limit the overall CEC of exported sediments. We would therefore expect the CEC flux over dissolved flux ratio to decrease with increasing erosion or sediment yield. Accordingly, the relative importance of CEC fluxes compared to dissolved fluxes is probably limited for most large fluvial systems. Notable exceptions that would require a more precise quantification of CEC fluxes include rivers draining volcanic areas, as these areas are known to export high-surface-area and smectite-rich sediments (e.g. Chen, 1978). Organic-rich rivers should also be considered, as the presence of organic matter may yield a high overall CEC (e.g. Thompson et al., 1989; Turpault et al., 1996) susceptible to altering the dissolved fluxes more significantly. In any case, it is important to stress that these future evaluations should take into account the variable CEC of sediments with sampling depth so as to correctly evaluate the integrated $\mathrm{CEC}$ of a river system. The evaluation of estuarine exchange processes may also be important to better understand the delivery of trace elements to the ocean (e.g. von Blanckenburg and Bouchez, 2014) or for possible isotopic fractionation of light elements during exchange.

Table 3 shows that only less than $1 \%$ of the dissolved riverine $\mathrm{Na}^{+}$load but ca. $8 \%$ of $\mathrm{K}^{+}, 6 \%$ of the $\mathrm{Ca}^{2+}$ and $3 \%$ of the $\mathrm{Mg}^{2+}$ are carried by sediments as exchangeable cations in the river system. These related fluxes are therefore typically not accounted for when the major elemental composition or river water is used in the context of determining upstream chemical weathering rates (Gaillardet et al., 1999). Although overall small, these "missing" fluxes are of a similar order of magnitude to cyclic salt corrections commonly applied to river water compositions for $\mathrm{K}^{+}, \mathrm{Ca}^{2+}$ and $\mathrm{Mg}^{2+}$ (e.g. Galy et al., 1999). Riverine dissolved compositions are 
also largely used to apportion the contribution of silicate and carbonate weathering to the total riverine $\mathrm{Ca}^{2+}$ flux. This is generally based on the total $\mathrm{Na}^{+}$and $\mathrm{K}^{+}$fluxes (as these are assumed to be unambiguously released by silicate weathering) and estimates of the $\mathrm{Ca} / \mathrm{Na}$ and $\mathrm{Ca} / \mathrm{K}$ composition of weathered source rocks (Gaillardet et al., 1999). The preferential uptake of $\mathrm{Ca}^{2+}$ and $\mathrm{K}^{+}$compared to $\mathrm{Na}^{+}$by cation exchange in the riverine environment will affect the measured dissolved $\mathrm{Ca} / \mathrm{Na}$ ratios $(\mathrm{Ca} / \mathrm{K}$ being less affected as both cations are taken up in very similar proportions). It has been suggested that these effects could be significant (Tipper, 2015). However, in the case of the G\&B the change in the measured dissolved $\mathrm{Ca} / \mathrm{Na}$ ratio due to the differential uptake of $\mathrm{Ca}$ and $\mathrm{Na}$ is about $5 \%$, which is most presumably well within the overall uncertainty of the carbonate and silicate weathering apportionment.

\subsection{Effect of cation exchange on the long-term carbon budget of Himalayan erosion}

The effect of continental weathering on the long-term carbon cycle is mainly dictated by dissolved fluxes derived from carbon-silicate weathering following the Ebelmen-Urey reaction (Eq. 1) because it can directly lead to precipitation of carbonate. This reaction stabilizes half of the alkalinity flux used to dissolve the initial silicates and release the other half as $\mathrm{CO}_{2}$ to the ocean and atmosphere. Silicate-derived $\mathrm{Mg}$ fluxes are also similarly efficient as they are exchanged for $\mathrm{Ca}$ during oceanic crust alteration or consumed during Mg-rich calcite precipitation (Berner and Berner, 2012). In contrast, it is generally assumed that, in the long term, the uptake of $\mathrm{CO}_{2}$ by $\mathrm{Na}^{+}$or $\mathrm{K}^{+}$silicate weathering (Eq. 3) is balanced by the $\mathrm{CO}_{2}$ release during the formation of new $\mathrm{Na}$ and $\mathrm{K}$ silicates on the seafloor during reverse weathering reactions (Eq. 4) (MacKenzie and Garrels, 1966).

$$
\begin{aligned}
& 2(\mathrm{Na}, \mathrm{K}) \mathrm{AlSi}_{3} \mathrm{O}_{8}+2 \mathrm{CO}_{2}+11 \mathrm{H}_{2} \mathrm{O} \rightarrow 2\left(\mathrm{Na}^{+} \mathrm{K}^{+}\right) \\
& +2 \mathrm{HCO}_{3^{-}}+4 \mathrm{H}_{4} \mathrm{SiO}_{4}+\mathrm{Al}_{2} \mathrm{Si}_{2} \mathrm{O}_{5}(\mathrm{OH})_{4}(\text { clay mineral }) \\
& \text { clay mineral }+\mathrm{HCO}_{3^{-}}+\mathrm{H}_{4} \mathrm{SiO}_{4}+\left(\mathrm{Na}^{+} \mathrm{K}^{+}\right) \\
& \rightarrow(\mathrm{Na}, \mathrm{K})_{\text {silicate }}+\mathrm{CO}_{2}+\mathrm{H}_{2} \mathrm{O}
\end{aligned}
$$

In such a case, $\mathrm{Na}$ and $\mathrm{K}$ silicate weathering does not participate in the long-term carbon budget of continental erosion. Alternatively, cation exchange reaction allows exchange of $\mathrm{Na}^{+}$or $\mathrm{K}^{+}$for $\mathrm{Ca}^{2+}$ and may subsequently lead to $\mathrm{CaCO}_{3}$ precipitation and long-term carbon sequestration (Eq. 5) (Berner, 2004; Berner et al., 1983; MacKenzie and Garrels, 1966; Michalopoulos and Aller, 1995).

$$
\begin{aligned}
& \mathrm{Ca}_{\text {clay mineral }}+2 \mathrm{Na}^{+}+2 \mathrm{HCO}_{3^{-}} \rightarrow 2 \mathrm{Na}_{\text {clay mineral }} \\
& +\mathrm{Ca}^{2+}+2 \mathrm{HCO}_{3^{-}} \mathrm{Ca}^{2+}+2 \mathrm{HCO}_{3^{-}} \\
& \rightarrow \mathrm{CaCO}_{3}+\mathrm{CO}_{2}+\mathrm{H}_{2} \mathrm{O} .
\end{aligned}
$$

Assuming annual exchange fluxes as discussed above (Table 3), $27 \times 10^{9} \mathrm{~mol} \mathrm{yr}^{-1} \mathrm{Na}^{+}$and $5 \times 10^{9} \mathrm{~mol} \mathrm{yr}^{-1} \mathrm{~K}^{+}$ would be exchanged for $16 \times 10^{9} \mathrm{~mol} \mathrm{yr}^{-1} \mathrm{Ca}^{2+}$, which can ultimately precipitate as $\mathrm{CaCO}_{3}$. This is substantial but remains relatively marginal compared to the total flux of silicate-derived alkalinity of the G\&B that is estimated to be around $270 \times 10^{9} \mathrm{~mol} \mathrm{yr}^{-1}$ (Galy and France-Lanord, 1999). In total, 60 to $65 \%$ of this silicate alkalinity is balanced by $\mathrm{Na}^{+}$and $\mathrm{K}^{+}$, which corresponds to 160 to $175 \times 10^{9} \mathrm{~mol} \mathrm{yr}^{-1}$ of $\mathrm{HCO}_{3}^{-}$. Therefore, about $10 \%$ of the alkalinity linked to $\mathrm{Na}-\mathrm{K}$ silicate weathering could finally lead to carbonate precipitation through cation exchange. Hence, the total flux of silicate-weathering-derived alkalinity that can precipitate as $\mathrm{CaCO}_{3}$ is 55 to $62 \times 10^{9} \mathrm{~mol} \mathrm{yr}^{-1}$. This estimate remains highly speculative since the extent and magnitude of reverse weathering reactions are currently poorly quantified.

These fluxes may be substantial but are still limited when compared to the ca. $300 \times 10^{9} \mathrm{~mol} \mathrm{yr}^{-1} \mathrm{C}$ storage associated to the organic carbon burial fluxes of the modern Himalayan system (Galy et al., 2007), which remains the main forcing of the carbon cycle from Himalayan erosion. It should nevertheless be kept in mind that our estimates are formulated based on the Himalayan system at present. On longer timescales, the variability in both sediment (Goodbred and Kuehl, 2000) and weathering fluxes (Lupker et al., 2013) means that the relative importance of cation exchange fluxes in the global weathering budget has likely varied and hence should be treated carefully. Finally, it is worth mentioning that these estimates of weathering impact on the carbon cycle do not take into account the role of chemical weathering through sulfuric acid (Galy and France-Lanord, 1999; Turchyn et al., 2013) that is known to also contribute to the weathering budget of Himalayan erosion and does counteract long-term carbon sequestration (Calmels et al., 2007).

\section{Conclusions}

The G\&B is the highest sediment point source of sediment to the oceans with an export of about 1 billion tonnes of sediments every year. The high average sediment concentration suggests that the cation exchange fluxes of this system may be significant or at least need to be quantified in order to derive robust weathering flux estimates. The flux of exchangeable cations has been quantified in this study based on CEC measurements of riverine sediments. These measurements show that the CEC of sediments is strongly variable within the water column, which is linked to sediment sorting effects and variable mineralogical composition with depth. Contrary to the total CEC, the nature of adsorbed cations is remarkably constant amongst all samples with the dominance of divalent cations $\mathrm{Ca}^{2+}$ and $\mathrm{Mg}^{2+}$. The equilibrium constants between adsorbed cations and river water composition of the G\&B are also very close to the ones derived for sediments from the Amazon in a previous study. 
Based on the sediment flux of the G\&B and assuming a total exchange of adsorbed riverine $\mathrm{Ca}^{2+}$ for marine $\mathrm{Na}^{+}$, we estimated that estuarine cation exchange could increase the dissolved $\mathrm{Ca}^{2+}$ flux to the ocean by $6 \%$ at most. Taking more realistic estimations based on a partial exchange of riverine $\mathrm{Ca}^{2+}$ for marine $\mathrm{Na}^{+}, \mathrm{Mg}^{2+}$ and $\mathrm{K}^{+}$yields an increased $\mathrm{Ca}^{2+}$ flux of ca. $5 \%$, while the equivalent of $15 \%$ of the dissolved $\mathrm{Na}^{+}$flux, $8 \%$ of the dissolved $\mathrm{K}^{+}$flux and $4 \%$ of the $\mathrm{Mg}^{2+}$ is reabsorbed by the sediments in the estuaries. Estuarine sediment-seawater cation exchange is therefore mainly a riverine $\mathrm{Na}^{+}$sink. In the context of the longterm carbon budget of Himalayan erosion, cation exchange increases the pool of $\mathrm{Ca}^{2+}$ that can contribute to $\mathrm{CaCO}_{3}$ storage. This additional flux is, however, limited to ca. $10 \%$ of the $\mathrm{Ca}-\mathrm{Mg}$ silicate-derived flux. In spite of the very intense particle flux associated to physical erosion of the Himalaya, the cation exchange process occurring in the estuarine zone does not significantly change the estimate of the impact of silicate weathering on long-term carbon sequestration. It is likely limited by the relatively coarse nature and low surface area of Himalayan sediments that lead to an overall low CEC.

Acknowledgements. This project benefited from funding of the INSU-Relief de le Terre national programme and OTELo Nancy inter-laboratory programmes. In Bangladesh, Mustafizur Rahman provided invaluable support to our sampling campaigns. We also thank Jeremy Caves, an anonymous reviewer and the editor, Robert Hilton, for helpful and constructive comments on this manuscript.

Edited by: R. Hilton

Reviewed by: J. Caves and one anonymous referee

\section{References}

Aran, D., Maul, A., and Masfaraud, J.-F.: A spectrophotometric measurement of soil cation exchange capacity based on cobaltihexamine chloride absorbance, C. R. Geosci., 340, 865-871, 2008.

Berner, E. K. and Berner, R. A.: Global environment : water, air, and geochemical cycles, Princeton University Press, Princeton, NJ, USA, 2012.

Berner, R. A.: The phanerozoic carbon cycle : $\mathrm{CO}_{2}$ and $\mathrm{O}_{2}$, Oxford University Press, Oxford, NY, USA, 2004.

Berner, R. A. and Berner, E.: Global Environment: Water, Air, and Geochemical Cycles, Prentice Hall, Princeton and Oxford, USA and UK, 1996.

Berner, R. A., Lasaga, A. C., and Garrels, R. M.: The carbonatesilicate geochemical cycle and its effect on atmospheric carbon dioxide over the past 100 million years, Am. J. Sci., 1983, 641683, 1983.

Bouchez, J., Lupker, M., Gaillardet, J., France-Lanord, C., and Maurice, L.: How important is it to integrate riverine suspended sediment chemical composition with depth? Clues from Amazon River depth-profiles, Geochim. Cosmochim. Ac, 75, 6955-6970, 2011.
Calmels, D., Gaillardet, J., Brenot, A., and France-Lanord, C.: Sustained sulfide oxidation by physical erosion processes in the Mackenzie River basin: Climatic perspectives, Geology, 35, 1003, 2007.

Chen, P.-Y.: Minerals in bottom sediments of the South China Sea, Geol. Soc. Am. Bull., 89, 211-222, 1978.

Ciesielski, H. , Sterckeman, T., Santerne, M., and Willery, J. P.: Determination of cation exchange capacity and exchangeable cations in soils by means of cobalt hexamine trichloride. Effects of experimental conditions, Agronomie, 17, 1-7, 1997.

Dohrmann, R. and Kaufhold, S.: Three new, quick CEC methods for determining the amounts of exchangeable calcium cations in calcareous clays, Clay. Clay Miner., 57, 338-352, 2009.

Ebelmen, J. J.: Sur les produits de la décomposition des espèces minérales de la famille des silicates, Ann. Mines, 7, 3-66, 1845.

France-Lanord, C. and Derry, L. A.: Organic carbon burial forcing of the carbon cycle from Himalayan erosion, Nature, 390, 65-67, doi:10.1038/36324, 1997.

Gaillardet, J., Dupré, B., Louvat, P., and Allègre, C. J.: Global silicate weathering and $\mathrm{CO}_{2}$ consumption rates deduced from the chemistry of large rivers, Chem. Geol., 159, 3-30, 1999.

Galy, A. and France-Lanord, C.: Weathering processes in the Ganges-Brahmaputra basin and the riverine alkalinity budget, Chem. Geol., 159, 31-60, 1999.

Galy, A. and France-Lanord, C.: Higher erosion rates in the Himalaya: Geochemical constraints on riverine fluxes, Geology, 29, 23-26, 2001.

Galy, V., France-Lanord, C., Beyssac, O., Faure, P., Kudrass, H., and Palhol, F.: Efficient organic carbon burial in the Bengal fan sustained by the Himalayan erosional system, Nature, 450, 407U406, 2007.

Galy, V., France-Lanord, C., and Lartiges, B.: Loading and fate of particulate organic carbon from the Himalaya to the GangaBrahmaputra delta., Geochim. Cosmochim. Ac., 72, 1767-1787, 2008.

Garzanti, E., Ando, S., France-Lanord, C., Censi, P., Vignola, P., Galy, V., and Lupker, M.: Mineralogical and chemical variability of fluvial sediments 2. Suspended-load silt (Ganga-Brahmaputra, Bangladesh), Earth Planet. Sc. Lett., 302, 107-120, 2011.

Goodbred, S. and Kuehl, S.: Enormous Ganges-Brahmaputra sediment discharge during strengthened early Holocene monsoon, Geology, 28, 1083-1086, 2000.

Heroy, D., Kuehl, S., and Goodbred, S.: Mineralogy of the Ganges and Brahmaputra rivers: Implications for river switching and Late Quaternary climate change, Sediment. Geol., 155, 343-359, 2003.

Holland, H. D.: The Chemistry of the Atmosphere and Oceans, Wiley \& Sons, New York, USA, 1978

Huyghe, P., Guilbaud, R., Bernet, M., Galy, A., and Gajurel, A. P.: Significance of the clay mineral distribution in fluvial sediments of the Neogene to Recent Himalayan Foreland Basin (west-central Nepal), Basin Res., 23, 332-345, 2011.

Jones, M. T., Pearce, C. R., and Oelkers, E. H.: An experimental study of the interaction of basaltic riverine particulate material and seawater, Geochim. Cosmochim. Ac., 77, 108-120, 2012.

Lupker, M.: Dynamique sédimentaire; érosion physique et altération chimique dans le système himalayen, $\mathrm{PhD}$, Centre de Recherches Pétrographiques et Géochimiques, Institut Polytechnique de Lorraine, Nancy, France, 2011. 
Lupker, M., France-Lanord, C., Lavé, J., Bouchez, J., Galy, V., Métivier, F., Gaillardet, J., Lartiges, B., and Mugnier, J.-L.: A Rouse-based method to integrate the chemical composition of river sediments: Application to the Ganga basin, J. Geophys. Res., 116, F04012, 2011.

Lupker, M., France-Lanord, C., Galy, V., Lavé, J., Gaillardet, J., Gajurel, A. P., Guilmette, C., Rahman, M., Singh, S. K., and Sinha, R.: Predominant floodplain over mountain weathering of Himalayan sediments (Ganga basin), Geochim. Cosmochim. Ac., 84, 410-432, 2012.

Lupker, M., France-Lanord, C., Galy, V., Lavé, J., and Kudrass, H.: Increasing chemical weathering in the Himalayan system since the Last Glacial Maximum, Earth Planet. Sc. Lett., 365, 243252, 2013.

MacKenzie, F. and Garrels, R. M.: Chemical Mass Balance between Rivers and Oceans, Am. J. Sci., 264, 507-525, 1966.

Malcolm, R. L. and Kennedy, V. C.: Variation of cation exchange capacity and rate with particle-size in stream sediment, J. Water Pollut. Con. F., 42, R153-R160, 1970.

Martinelli, L. A., Victoria, R. L., Dematte, J. L. I., Richey, J. E., and Devol, A. H.: Chemical and mineralogical composition of Amazon River floodplain sediments, Brazil, Appl. Geochem., 8, 391-402, 1993.

Michalopoulos, P. and Aller, R. C.: Rapid Clay Mineral Formation in Amazon Delta Sediments: Reverse Weathering and Oceanic Elemental Cycles, Science, 270, 614-617, 1995.

Milliman, J. D. and Farnsworth, K. L.: River discharge to the coastal ocean: a global synthesis, Cambridge University Press, Cambridge, NY, USA, 2011.

Orsini, L. and Remy, J. C.: Utilisation du chlorure de cobaltihexamine pour la détermination simultanée de la capacité d'échange et des bases échangeables des sols., Sci. Sol., 4, 269-275, 1976.

Raymo, M. and Ruddiman, W.: Tectonic forcing of late Cenozoic climate, Nature, 359, 117-122, 1992.

RSP: River Survey Project, Flood Action Plan (FAP) final report, Delft Hydraulics and DHI, 1996.

Sayles, F. and Mangelsdorf, P.: Equilibration of clay minerals with seawater - Exchange reactions, Geochim. Cosmochim. Ac., 41, 951-960, 1977.
Sayles, F. and Mangelsdorf, P.: Cation-exchange characteristics of Amazon River suspended sediment and its reaction with seawater, Geochim. Cosmochim. Ac., 43, 767-779, 1979.

Singh, S. K., Sarin, M. M., and France-Lanord, C.: Chemical erosion in the eastern Himalaya: Major ion composition of the Brahmaputra and delta C-13 of dissolved inorganic carbon, Geochim. Cosmochim. Ac., 69, 3573-3588, 2005.

Thompson, M. L., Zhang, H., Kazemi, M., and Sandor, J. A.: Contribution of organic matter to cation exchange capacity and specific surface area of fractionated soil materials, Soil Sci., 148, 250-257, 1989.

Tipper, E.: Re-Assessing The Weathering Signature Of Continental Waters: Constraints from $\mathrm{Mg}$ and $\mathrm{Li}$ isostope ratios, AGU Fall Meeting, San Francisco, USA, 14-18 December 2015, Paper/82890, 2015.

Turchyn, A. V., Tipper, E. T., Galy, A., Lo, J. K., and Bickle, M. J.: Isotope evidence for secondary sulfide precipitation along the Marsyandi River, Nepal, Himalayas, Earth Planet. Sc. Lett., 374, 36-46, 2013.

Turpault, M. P., Bonnaud, P., Fighter, J., Ranger, J., and Dambrine, E.: Distribution of cation exchange capacity between organic matter and mineral fractions in acid forest soils (Vosges mountains, France), Eur. J. Soil Sci., 47, 545-556, 1996.

Urey, H. C.: The Planets: their origin and development, Yale University Press, New Haven, CT, USA, 1952.

von Blanckenburg, F. and Bouchez, J.: River fluxes to the sea from the ocean's 10Be/9Be ratio, Earth Planet. Sc. Lett., 387, 34-43, 2014.

Walker, J., Hays, P., and Kasting, J.: A negative feedback mechanism for the long-term stabilization of the Earth's surface temperature, J. Geophys. Res., 86, 9776-9782, 1981.

West, A. J., Galy, A., and Bickle, M.: Tectonic and climatic controls on silicate weathering, Earth Planet. Sc. Lett., 235, 211228, 2005. 